\title{
Experimenting biochemical oxygen demand decay rates of Malaysian river water in a laboratory flume
}

\author{
Md. Nuruzzaman ${ }^{1}$, Abdullah Al-Mamun ${ }^{\dagger}$, Md. Noor Bin Salleh ${ }^{3}$ \\ ${ }^{1}$ Department of Civil Engineering, Rangpur Engineering College, Rangpur - 5403, Bangladesh \\ 2Department of Civil Engineering, Kulliyyah of Engineering International Islamic University Malaysia (IIUM), Jalan Gombak, 53100 Kuala Lumpur, \\ Malaysia \\ ${ }^{3}$ Bioenvironmental Engineering Research Center (BERC), Kulliyyah of Engineering International Islamic University Malaysia (IIUM), Jalan Gombak, \\ 53100 Kuala Lumpur, Malaysia
}

\begin{abstract}
Lack of information on the Biochemical Oxygen Demand (BOD) decay rates of river water under the tropical environment has triggered this study with an aim to fill the gap. Raw sewage, treated sewage, river water and tap water were mixed in different proportions to represent river water receiving varying amounts and types of wastewater and fed in a laboratory flume in batch mode. Water samples were recirculated in the flume for $30 \mathrm{~h}$ and BOD and Carbonaceous BOD (CBOD) concentrations were measured at least six times. Decay rates were obtained by fitting the measured data in the first order kinetic equation. After conducting 12 experiments, the range of BOD and CBOD decay rates were found to be 0.191 to 0.92 per day and 0.107 to 0.875 per day, respectively. Median decay rates were 0.344 and 0.258 per day for BOD and $\mathrm{CBOD}$, respectively, which are slightly higher than the reported values in literatures. A relationship between CBOD decay rate and BOD decay rate is proposed as $k_{C B O D}=0.8642 k_{B O D}-0.0349$ where, $k_{C B O D}$ is CBOD decay rate and $k_{B O D}$ is BOD decay rate. The equation can be useful to extrapolate either of the decay rates when any of the rates is unknown.
\end{abstract}

Keywords: BOD, Decay rate, Kinetics, Laboratory flume, Water quality modeling

\section{Introduction}

River systems are increasingly degraded due to discharge of wastes generated in municipal, industrial and agricultural areas into the rivers and tributaries [1]. Water quality models are extensively being used, these days, to deal with water quality management issues [2, 3]. Modeling allows varying the existing input variables to achieve future desired conditions. Thus different alternative scenarios can be modeled through which cost and benefits of each of the outcomes can be analyzed to choose the best option to improve water quality $[4,5]$. However, before simulating different scenarios, the model needs to be calibrated and validated [6]. Comprehensive calibration and validation of a model is extremely essential for reliable outcomes of the model [7]. One of the major steps in calibrating and validating water quality models is to vary water quality kinetic rates until the model predicted values come into good agreement with the observed data. Therefore, determination of kinetic parameters is very important for reliable water quality modeling [8]. Many researchers have determined the typical rates of water quality kinetics for various parameters in different parts of the world by using laboratory and field methods. However, typical surface water quality kinetic rates are available in the developed countries, whereas not much is known about the water quality kinetic rates of the remaining part of the world, where the climate, environment and nature of pollution is different. After calibration and validation of a river water quality model, the kinetic rates are usually compared with the typical values of that region, which cannot be done in the case of tropical climatic areas due to lack of study on river water quality kinetics in this region. In fact, there is no detail study conducted to determine the pollutant decay rates and kinetics for tropical climate. As such, the objective of this study is to determine the decay rates of two important river water quality parameters, e.g. Biochemical Oxygen Demand (BOD) and Carbonaceous Biochemical Oxygen Demand (CBOD) for tropical environment of Malaysia.

In most of the studies involving kinetic determination of BOD
This is an Open Access article distributed under the terms of the Creative Commons Attribution Non-Commercial License (http://creativecommons.org/licenses/by-nc/3.0/) which permits unrestricted non-commercial use, distribution, and reproduction in any medium, provided the original work is properly cited.
Received April 14, 2017 Accepted September 5, 2017

${ }^{\dagger}$ Corresponding author

Email: mamun@iium.edu.my

Tel: $+60-123650516$

Copyright (C) 2018 Korean Society of Environmental Engineers 
or CBOD, bottle rate is used. However, the bottle kinetic rate does not represent real river conditions, because the bottle water is stagnant and tranquil, whereas real river water is flowing and have turbulence $[9,10]$. The field method of determining BOD or CBOD kinetic rate has also some complexities as uniform cross-section of river section, uniform flow, single point source are preconditions for field investigation [11]. The novelty in the methodology of this study is the use of laboratory flume, which simulates the turbulent condition of a river. Another important aspect is that this study aims at filling the gap of information regarding BOD and CBOD kinetics in tropical climatic condition of Malaysia.

$\mathrm{BOD}$ is a very important river water quality parameter, which affects Dissolved Oxygen (DO) concentration of water. Every river has its own self-purification mechanism for every degradable pollutant [12, 13], among which biological decay of pollutants is a natural treatment for river water [14-16]. To model the DO concentration of a river, it is essential to know BOD kinetics as BOD is a sink for DO. Streeter-Phelps equation is used for DO mass balance. Eq. (1) is the classic Streeter-Phelps DO mathematical model and Eq. (2) is the modified one [10, 17].

$$
\begin{gathered}
D=D_{0} e^{-k_{a} t}+\frac{k_{d} L_{0}}{k_{a}-k_{d}}\left(e^{-k_{d} t}-e^{-k_{a} t}\right) \\
D=D_{0} e^{-k_{d} t}+\frac{k_{d} L_{0}}{k_{a}-k_{r}}\left(e^{-k_{r} t}-e^{-k_{a} t}\right)+\frac{k_{n} L_{n 0}}{k_{a}-k_{n}}\left(e^{-k_{r} t}-e^{-k_{a} t}\right)
\end{gathered}
$$

where, for both Eq. (1) and Eq. (2), $D$ is the oxygen deficit after travel time ' $t$ '; $D_{o}$ is the initial oxygen deficit; $k_{a}$ is the reaeration rate coefficient; $t$ is the travel time. For Eq. (1), $k_{d}$ is the BOD

Table 1. Typical BOD Decay Rate

\begin{tabular}{ccc}
\hline \multirow{2}{*}{ Treatment } & \multicolumn{2}{c}{$\mathbf{k}_{\mathbf{d}}\left(\mathbf{2 0}{ }^{\circ} \mathbf{C}\right)$} \\
\cline { 2 - 3 } & Average & Range \\
\hline Untreated & 0.35 & $0.20-0.50$ \\
Treated & 0.20 & $0.10-0.30$ \\
Activated Sludge & 0.075 & $0.05-0.10$ \\
\hline
\end{tabular}

decay rate coefficient; $L_{o}$ is the ultimate BOD in the river. For Eq. (2), $k_{d}$ is the CBOD decay rate coefficient, $k_{n}$ is the NBOD or AN decay rate coefficient, $k_{r}$ is the CBOD removal rate coefficient, $L_{0}$ is the ultimate CBOD in the river after mixing, $L_{n o}$ is the ultimate NBOD in the river after mixing.

The modified Streeter-Phelps equation is more accurate than the classic equation, which considers CBOD and NBOD separately. However, if CBOD and NBOD data are not available separately, then the classic equation can be used to model DO of river water. Knowing typical regional decay rates of these pollutants is essential to compare the results of any water quality modeling studies. Chapra [18] mentioned some typical values of BOD decay rates (Table 1) based on the level of wastewater treatment. The data in Table 1 indicates that intensely treated wastewater tends to have lower decay rate compared to partially treated or raw sewage.

Table 2 presents BOD decay rates of some of the rivers across the world. The methods involved to determine the rates were calibration of computer models and laboratory study. The range of BOD decay rate has been found to be varying between 0.1 and 2.4 per day.

CBOD decay rates determined by different methods reported in different parts of the world are shown in Table 3. It can be observed that the CBOD decay rate can be as low as 0.001 per day and as high as 4.24 per day (Table 3). The methods of these studies involved calibration of computer models, field study and laboratory study.

Analysis of the decay rates found in the literatures has been depicted in Fig. 1 by box and whisker plot. It is noticeable that even if the range of decay rate is quite wide, the median value falls in the lower zone of the box. For BOD, the median value is 0.2 per day and for CBOD, it is 0.23 per day, whereas the maximum values are 2.4 and 4.24 per day for BOD and CBOD, respectively. The median value of BOD decay rate conforms with the suggested values by Chapra [18]. Furthermore, from the box plot, the third quartile is less than 0.4 per day and 1.2 per day for BOD and CBOD, respectively. Therefore, it can be expected that BOD and CBOD decay rate will remain below these values, whereas exceptionally high values might also be obtained occasionally.

\begin{tabular}{|c|c|c|c|}
\hline Location & BOD decay (per day) at $20^{\circ} \mathrm{C}$ & Method of study & Reference \\
\hline Kaoping River (Taiwan) & 0.24 & Model calibration & {$[25]$} \\
\hline Taihu Lake (China) & $0.163-0.477$ & Laboratory study & {$[27,28]$} \\
\hline Hongqi River (China) & 0.1 & QUAL2K model calibration & {$[27]$} \\
\hline Tan Sui River and its tributaries (Taiwan) & 0.15-0.6 & Laboratory study & [29] \\
\hline Bann River (UK) & 2.4 & HSPF model calibration & {$[30]$} \\
\hline Klamath River (USA) & $0.11-0.29$ & Laboratory study & {$[24]$} \\
\hline Keelung River (Taiwan) & 0.16 & QUAL2K model calibration & {$[31]$} \\
\hline Six Lakes & $0.044-0.14$ & Laboratory study & {$[32]$} \\
\hline San Joaquin River (California) & $0.03-0.09$ & Laboratory study & {$[33]$} \\
\hline Molenbeek Brook River (Belgium) & 0.5 & MIKE-11 model calibration & {$[34]$} \\
\hline Nakdong River (South Korea) & $0.2-0.4$ & QUAL2E model calibration & {$[35]$} \\
\hline
\end{tabular}

Table 2. Reported BOD Decay Rates in Several Rivers 
Table 3. Reported CBOD Decay Rates in Several Rivers

\begin{tabular}{|c|c|c|c|}
\hline Location & CBOD decay (per day) at $20^{\circ} \mathrm{C}$ & Method of study & Reference \\
\hline Wujin River (China) & 0.23 & QUAL2K model calibration & {$[36]$} \\
\hline Gharbia drain (Egypt) & $0.18-2.88$ & QUAL2K model calibration & {$[37]$} \\
\hline El-Qalaa drain & $0.18-2.92$ & QUAL2Kw model calibration & {$[38]$} \\
\hline Gargar River (Iran) & 0.3 & QUAL2K model calibration & [39] \\
\hline Ravi River (Pakistan) & 0.36 & Laboratory study & {$[40]$} \\
\hline Chungju Lake (South Korea) & 0.0082 & WASP model calibration & {$[41]$} \\
\hline Klamath River (USA) & $0.15-0.22$ & Laboratory study & {$[24]$} \\
\hline WASP manual & $0.001-4.24$ & - & [26] \\
\hline Sieve and Ombrone River (Italy) & 0.029-0.109 & Model calibration & {$[42]$} \\
\hline Bagmati River (Nepal) & 3.8 & QUAL2Kw model calibration & {$[1]$} \\
\hline QUAL2K manual & $0.02-3.4$ & - & {$[43]$} \\
\hline Skravad River (Denmark) & 0.15 & Field study & {$[44]$} \\
\hline White River (USA) & $0.004-0.66$ & Laboratory study & {$[45]$} \\
\hline Yamuna River (India) & 1.4 & Field study & {$[46]$} \\
\hline Speed River (Canada) & 1.0 & Field study & {$[47]$} \\
\hline Yampa River (USA) & 0.4 & Model calibration & {$[48]$} \\
\hline
\end{tabular}

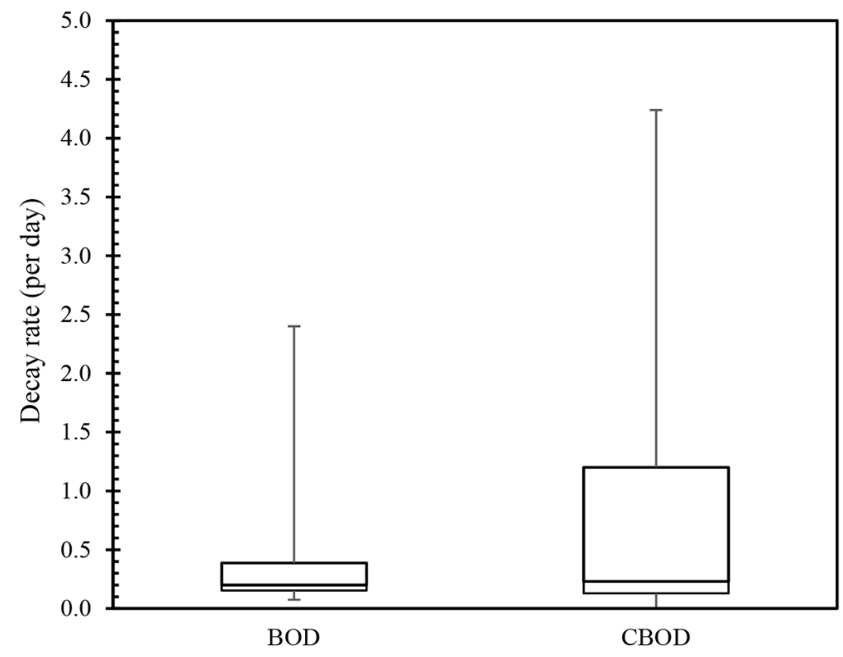

Fig. 1. Box plot of decay rates based on literature review.

\section{Materials and Methods}

The water samples used in the experiments of this study were prepared by mixing treated sewage, raw sewage, river water and tap water. Water from these sources was mixed in different proportions to represent river water receiving different amount of sewage. Treated sewage was collected from a Sewage Treatment Plant (STP) effluent inside IIUM Gombak Campus. Raw sewage was collected from café and residential hostel outlets. As the sources of treated and raw sewage of this study were from residential areas, hence it falls in domestic sewage category. Therefore, water samples prepared using these sewages represent river water receiv-

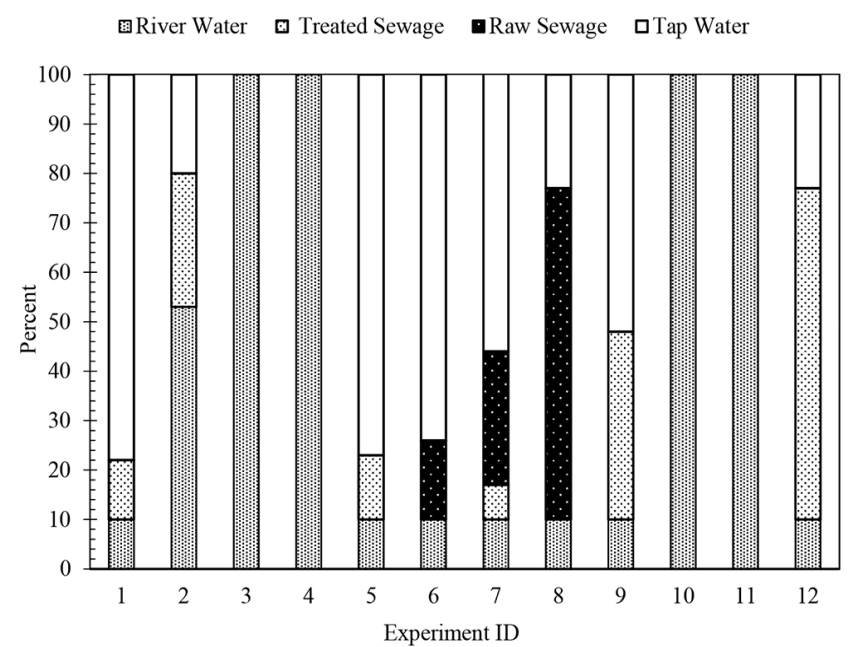

Fig. 2. Proportions of constituents of water samples used in the experiments.

ing domestic sewage only. Therefore, the scope of this study is rivers receiving domestic sewage only. However, there are four experiments for which water samples were directly collected from river and no tap water or sewage was added to that sample.

Fig. 2 shows details of water samples used in the decay rate experiments. For experiment 1, 5, 9 and 12, the water sample represents a river water receiving primary treated sewage only. The water sample in experiment 2 corresponds to a polluted river receiving primary treated sewage. The water samples of experiment 3, 4, 10 and 11 are actual river water from Pusu River, Batang Pusu, Anak Pusu and Gombak River, 
Table 4. Characteristics of Water Samples Used in the Experiments

\begin{tabular}{|c|c|c|c|c|c|c|c|}
\hline Experiment No. & Water type / Source & $\mathbf{p H}$ & TSS (mg/L) & $\mathrm{NH}_{3}-\mathrm{N}(\mathrm{mg} / \mathrm{L})$ & $\mathrm{NO}_{3}-\mathrm{N}(\mathrm{mg} / \mathrm{L})$ & BOD (mg/L) & CBOD (mg/L) \\
\hline 1 & SW & 7.96 & 87 & 2.50 & 0.2 & 47.3 & 41.0 \\
\hline 2 & SW & 7.43 & 70 & 4.20 & 3.0 & 76.0 & 53.3 \\
\hline 3 & Pusu River & 7.53 & 49 & 0.85 & 2.1 & 8.2 & 6.8 \\
\hline 4 & Batang Pusu & 7.91 & 38 & 0.89 & 0.2 & 16.1 & 14.6 \\
\hline 5 & SW & 7.51 & 42 & 2.24 & 0.2 & 266.2 & 246.0 \\
\hline 6 & SW & 7.40 & 31 & 1.00 & 0.4 & 89.0 & 77.8 \\
\hline 7 & SW & 7.65 & 52 & 2.15 & 0.3 & 106.4 & 72.4 \\
\hline 8 & SW & 7.99 & 79 & 4.44 & 0.2 & 122.3 & 97.8 \\
\hline 9 & SW & 8.08 & 111 & 8.45 & 0.7 & 90.9 & 65.4 \\
\hline 10 & Anak Pusu & 7.80 & 36 & 0.68 & 0.0 & 3.7 & 2.8 \\
\hline 11 & Gombak River & 7.60 & 58 & 1.08 & 0.2 & 6.0 & 4.9 \\
\hline 12 & SW & 8.21 & 214 & 9.80 & 0.0 & 38.4 & 31.6 \\
\hline
\end{tabular}

SW $=$ Synthetic Wastewater

respectively. Water samples in experiment 6 and 8 represent the water of a river receiving untreated sewage only. For experiment 7 , the water sample reflects a river receiving both primary treated sewage and raw sewage.

The use of different percentage of raw sewage or primary treated sewage can be justified by investigating how much wastewater a river receives in the real world. According to Haider [19], Ravi River in Pakistan receives a wastewater flow of two times of its actual flow, i.e. $67 \%$ of the total river water is wastewater in dry weather. In the case of Pusu River in Malaysia, it receives about $35 \%$ of wastewater of the total flow of the river in dry season. Anak Pusu, a tributary of Pusu River receives about $12 \%$ of wastewater of the total flow in dry weather. The percentage of wastewater was used within the above-mentioned range in the experiments. However, the amount of wastewater discharged into a river does not depend on climatic regions rather it depends on the density of population living by the near vicinity of a river.

Table 4 presents the characteristics of water samples used in the experiments. It is noteworthy to mention that $\mathrm{pH}$ value of all the experiments were mostly around 8, which implies slightly alkaline water. As the sewage mixed in the sample water were domestic sewage, which contains soap, detergents [20] along with other ingredients, the sample waters were demonstrating alkaline nature. Similar to the Pusu River, Batang Pusu, Anak Pusu and Gombak River also receives domestic sewage, $\mathrm{pH}$ of these waters were also greater than 7 . TSS values ranged between $31 \mathrm{mg} / \mathrm{L}$ to $214 \mathrm{mg} / \mathrm{L}$, which is typical concentration for a river during a non-rainy day. AN concentrations were between $0.68 \mathrm{mg} / \mathrm{L}$ to $9.80 \mathrm{mg} / \mathrm{L}$. For the four rivers, AN and BOD concentrations were around $1 \mathrm{mg} / \mathrm{L}$ and $10 \mathrm{mg} / \mathrm{L}$, respectively. In case of experiment number 5, BOD concentration was unusually high even though treated sewage and river water (in little amounts) were used along with tap water. One of the probable reasons might be that the sewage was not properly treated on that day.
Schematic of the experimental procedure is shown in Fig. 3. A laboratory flume of $1.7 \mathrm{~m}$ in length and $0.15 \mathrm{~m}$ in width was used to conduct the BOD and CBOD decay rate experiments. Once the water was prepared or collected, it was fed to the flume and recirculated by a submersible pump. The experiments were carried out up to $30 \mathrm{~h}$ continuously. Samples were collected at least 6 times during this period. However, at the end of the day time, i.e. in the night time, even if no sampling was done because of logistic limitations, the water was continuously recirculated and sampling was continued in the next day. Five day BOD and CBOD tests were performed for each collected sample.

Twelve experiments were conducted and for each batch of experiment, at least six data points were obtained through sampling and testing. The hydraulic condition of each experiment was kept constant at a depth of $0.1 \mathrm{~m}$ and a velocity of $0.2 \mathrm{~m} / \mathrm{s}$. Once all

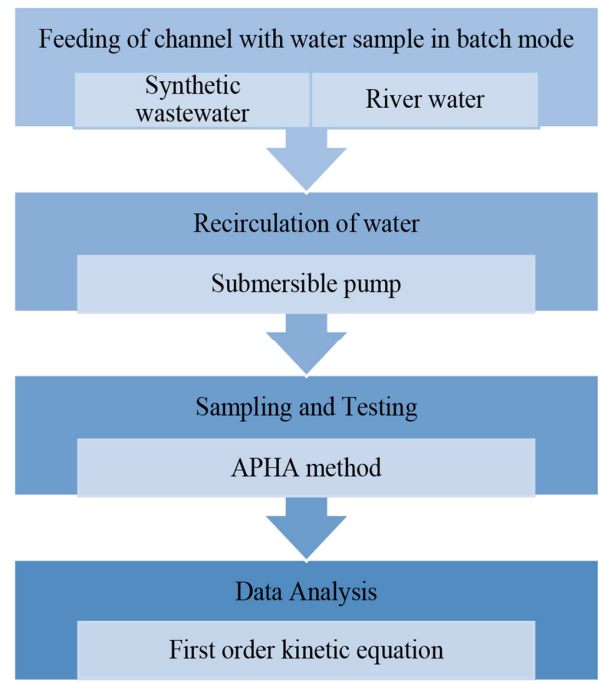

Fig. 3. Experimental procedure of determining kinetic rates. 
the test results were obtained, analysis of these data was performed to obtain the decay rates of BOD and CBOD. According to literature, the decay process of BOD and CBOD follow the first order kinetic equation [21, 22]. Eq. (3) is the first order kinetic equation.

$$
C=C_{0} e^{-k t}
$$

where, $C$ is the concentration of pollutant after a time ' $t$ '; $C_{0}$ is the initial concentration of pollutant; $t$ is the time in days; $k$ is the decay rate in day $^{-1}$.

The data obtained through the experiments was fitted in this equation by non-linear curve fitting method. The expression of first order kinetic equation was used and the ' $k$ value was solved for minimum Root Mean Square Error (RMSE). The decay rates obtained from the curve fitting method were extrapolated to rates at $20^{\circ} \mathrm{C}$ by using Eq. (4).

$$
k=k_{20} \theta^{T-20}
$$

where, $k_{20}$ is the $\mathrm{BOD}$ or $\mathrm{CBOD}$ decay rate at $20^{\circ} \mathrm{C} ; \theta$ is the temperature correction factor; $T$ is temperature; $k$ is the BOD or CBOD decay rate at $T^{\circ}$ C. $\theta=1.047[21]$.

Testing of samples were performed according to American Public Health Association (APHA) standard methods for the examination of water and wastewater [23].

\section{Results and Discussion}

Fig. 4 depicts a typical example of data fitting into the first order kinetic equation. The dots are the observed concentrations of BOD or CBOD and the solid line represents the predicted concentrations after solving the kinetic rates for minimum RMS error with respect to the observed values. The observed data are the measured concentrations of BOD or CBOD of the collected samples. Predicted line was calculated from Eq. (3) for minimum RMS error against the observed data.

The data fitting errors of BOD are shown in Fig. 5; in terms of RMS error and $\mathrm{R}^{2}$. In the case of BOD, minimum RMS error was found to be $0.08 \mathrm{mg} / \mathrm{L}$ for experiment 11, whereas initial concentration was $6 \mathrm{mg} / \mathrm{L}$. Experiment 5 produced maximum RMS error, i.e. $12.6 \mathrm{mg} / \mathrm{L}$, which also has the highest initial concentration, i.e. $266 \mathrm{mg} / \mathrm{L}$. The final concentrations of experiment 11 and 5 are $4.6 \mathrm{mg} / \mathrm{L}$ and $206.4 \mathrm{mg} / \mathrm{L}$, respectively. Therefore, maximum and minimum errors are insignificant compared to the initial and final concentrations of BOD. The RMS errors of the remaining experiments were also low compared to their corresponding initial and final concentrations except experiment 2. Initial and final BOD concentrations of experiment 2 were $76 \mathrm{mg} / \mathrm{L}$ and $24.7 \mathrm{mg} / \mathrm{L}$, respectively, whereas the RMS error was $9.24 \mathrm{mg} / \mathrm{L}$. Though, RMS error for experiment 2 is comparatively high in terms of corresponding initial and final concentrations, it is still within fair margin of acceptable limit. $\mathrm{R}^{2}$ values ranged between 0.74 and 0.99 for BOD, which is satisfactory.

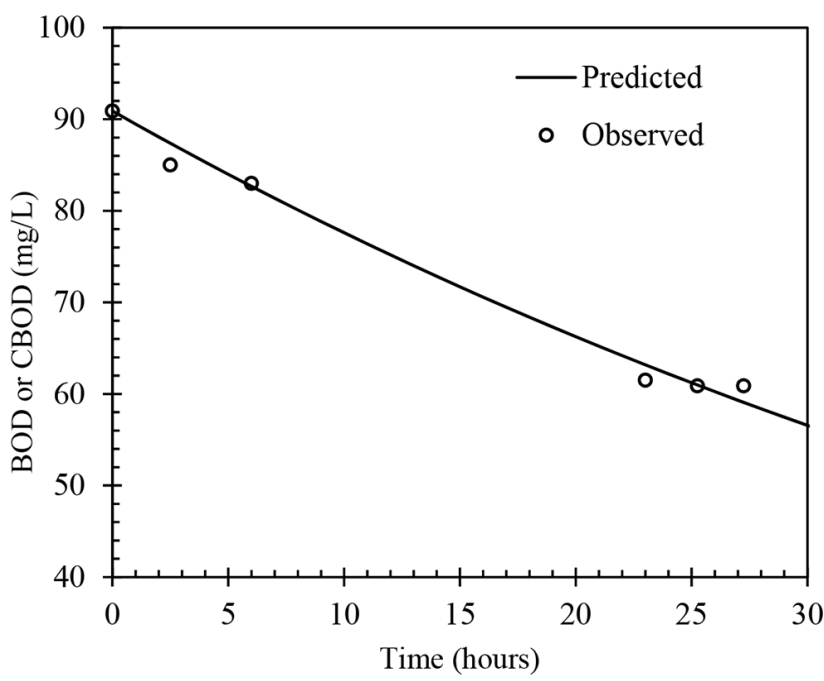

Fig. 4. Example of a BOD or CBOD decay curve.

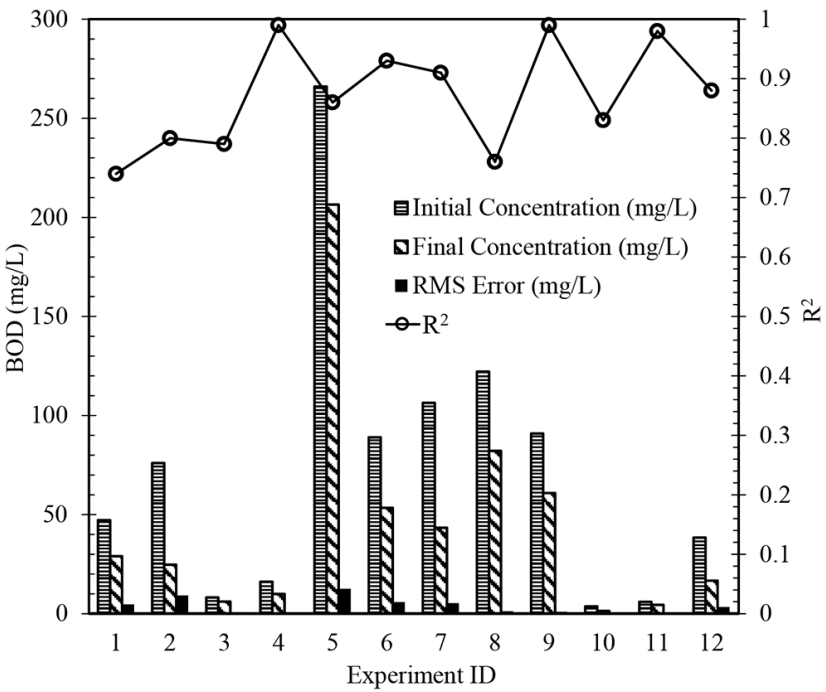

Fig. 5. Errors of BOD data fitting.

Fig. 6 illustrates the errors of CBOD data fitting. The lowest initial and final concentrations of CBOD were $2.8 \mathrm{mg} / \mathrm{L}$ and 1 $\mathrm{mg} / \mathrm{L}$ in experiment 10, whereas RMS error was $0.05 \mathrm{mg} / \mathrm{L}$, which is also the lowest amongst all the experiments. Though the highest initial and final concentrations of CBOD were observed in experiment 5, nevertheless, RMS error was only $2.61 \mathrm{mg} / \mathrm{L}$, which is not the highest value implying impressive agreement between observed and predicted data. The highest RMS error was found to be $6.84 \mathrm{mg} / \mathrm{L}$ in experiment 6 , which indicates relatively less accurate data set. However, initial and final CBOD concentrations in experiment 6 were $77.8 \mathrm{mg} / \mathrm{L}$ and $56 \mathrm{mg} / \mathrm{L}$, respectively, which is acceptable. On the other hand, $\mathrm{R}^{2}$ value was estimated to be more than 0.8 except experiment 11 implying strong agreement between observed and predicted data.

From literature review, BOD decay rates can be observed to be varying between 0.11 to 2.4 per day [24, 25], whereas CBOD 


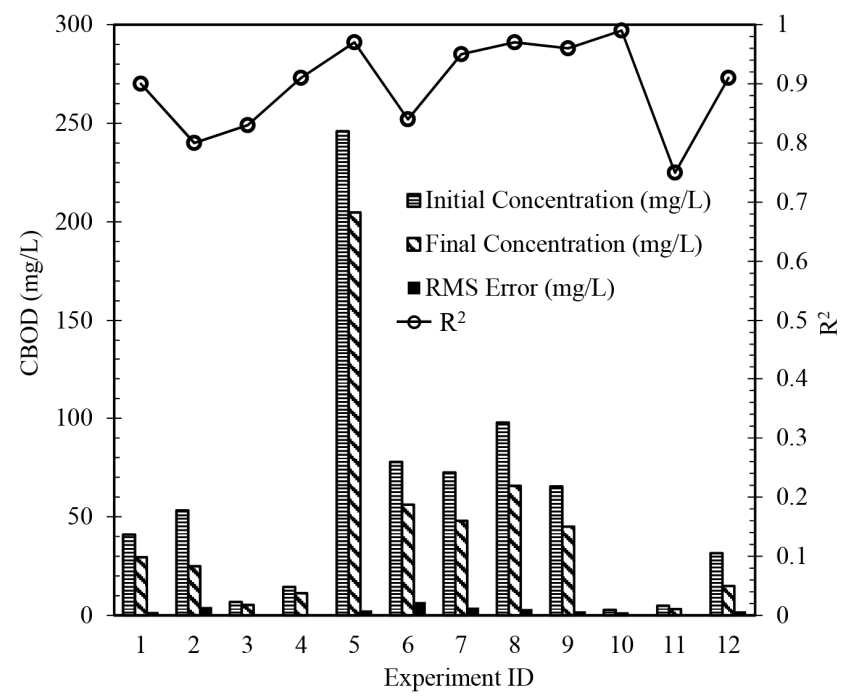

Fig. 6. Errors of $\mathrm{CBOD}$ data fitting.

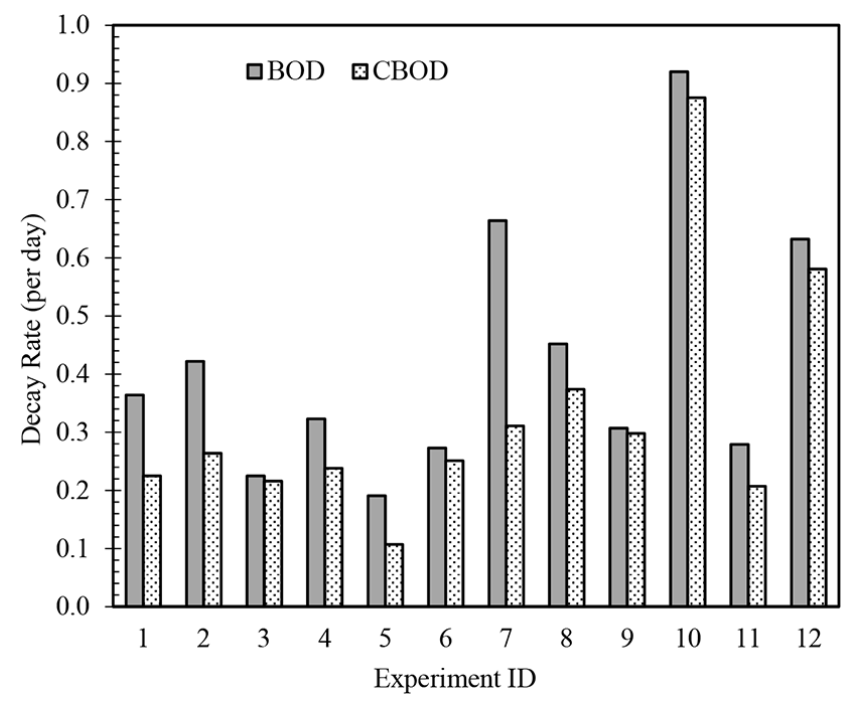

Fig. 7. Derived BOD and CBOD decay rates.

decay rate was found to be from 0.001 to 4.24 per day [26] for different rivers and lakes. BOD decay rates obtained from the experiments of this study have been shown in Fig. 7. Minimum BOD decay rate was 0.191 per day and maximum was 0.920 per day. CBOD decay rates in this study have been found to be within a range of 0.107 to 0.875 per day. However, it is also notable that BOD decay rates were mostly below 0.5 per day and CBOD decay rates were less than 0.3 per day in most of the cases. It is comprehensive from the results that both BOD and CBOD decay rates found in this study fall within the decay rates reported in literatures. Now, the range of BOD and CBOD decay rates for tropical environment of Malaysia has been identified from the wide global range, which is a contribution of knowledge for this region.

Another interesting thing, which is the relationship between the CBOD and BOD decay rate has been found in this study. Plotting CBOD decay rate $\left(k_{C B O D}\right)$ and BOD decay rate $\left(k_{B O D}\right)$ gives a linear relationship. $\mathrm{R}^{2}$ value for this plot was found to be 0.81 .

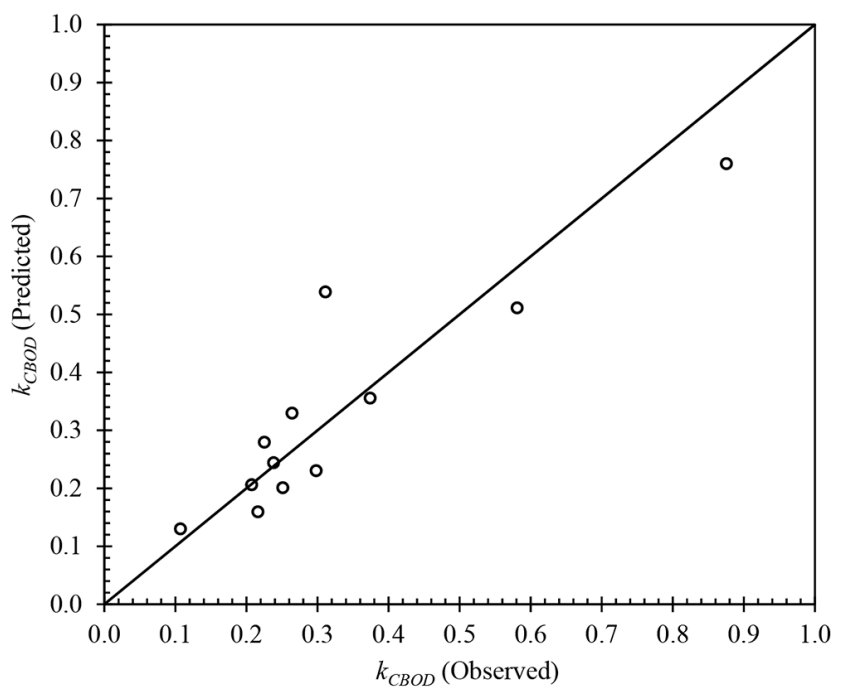

Fig. 8. Observed versus predicted plot of Eq. (5).

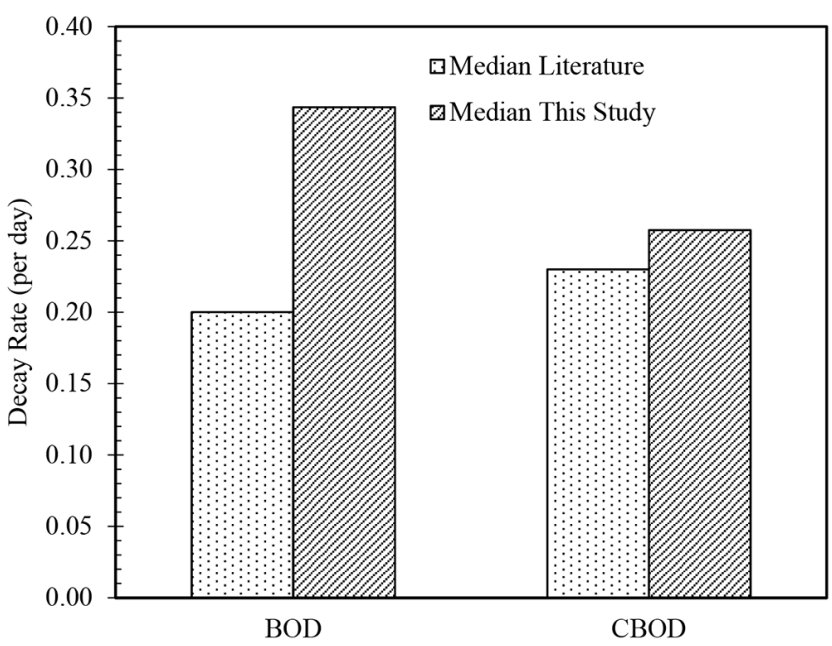

Fig. 9. Comparison of median value of decay rates of this study with literature review.

The equation of this relationship is given in Eq. (5). Observed and predicted plot of the equation is shown in Fig. 8.

$$
k_{C B O D}=0.8642 k_{B O D}-0.0349
$$

It was observed that BOD decay rate was always higher than that of CBOD decay rate, which is logical. The reason is that in a CBOD test, nitrifying bacterium is suppressed by inhibitors. Therefore, the availability of less number of oxygen consuming bacterium slows down the process of DO depletion, yielding a lower decay rate. However, the relationship between BOD decay rate and CBOD decay rate should also vary depending upon the ratio of carbonaceous bacteria and nitrogenous bacteria, which is really difficult to measure. In this study, the detail investigation is excluded and only the relationship is proposed.

However, this type of relationship between BOD decay rate and CBOD decay rate has never been reported previously in the 
literature. Therefore, this relationship needs to be verified by extensive number of experiments. The equation can be very much useful to estimate or verify CBOD decay rate when only BOD decay rate is available and CBOD decay rate is not available or vice versa.

Comparison of decay rates of this study with literature review is shown in Fig. 9. The median value of both BOD decay rate and CBOD decay rate of this study was found to be higher than the values reported in literature. The median value of BOD decay rate from literatures is 0.2 per day, whereas in this study, it is 0.344 per day. For CBOD, median value of decay rate from literature is 0.23 per day and from this study, it is 0.258 per day, which is slightly higher.

If the range of decay rates for any of the parameters of this study is compared with the literature, it is obvious that the range of decay rate for tropical climate region is much shorter than the global range, which is a significant contribution of knowledge derived from this study. The range of BOD and CBOD decay rate was from 0.075 to 2.4 per day and 0.001 to 4.24 per day, respectively. On the other hand, this study revealed that the range for tropical climate should be from 0.191 to 0.92 per day and 0.107 to 0.875 per day for BOD and CBOD, respectively. The implication of the results is that water quality modelers in Malaysia and other tropical region can choose value of decay rates reported in this study to calibrate and validate river water quality models.

\section{Conclusions}

The results of the experiments yielded that BOD decay rate of rivers under tropical environmental condition of Malaysia and other places may vary between 0.191 to 0.920 per day and CBOD decay rate can be within 0.107 to 0.875 per day. Median values of BOD and CBOD decay rates were observed to be 0.344 per day and 0.258 per day, respectively, which are slightly higher than the reported median values of BOD and CBOD decay rates. It can be also concluded that the range of BOD and CBOD decay rates for Malaysian river water under the tropical environment has been significantly shortened than the wide range of global BOD and CBOD decay rates. Now, it would be easy for water quality modelers to choose as well as compare BOD and CBOD decay rates for Malaysian river water, with confidence. In addition to the decay rates, a relationship between BOD decay rate and CBOD decay rate has been proposed in this study. The relationship is described by the equation, $k_{C B O D}=0.8642 k_{B O D}-0.0349$. Such relations will assist the water quality professionals to conduct additional analysis and verifications related to BOD decay rates.

\section{Acknowledgments}

This study was funded by Ministry of Science, Technology and Innovation (MOSTI), Malaysia (Grant No. SF14-009-0059). Authors are also grateful to those who supported this work in various capacities.

\section{Nomenclature}

$C_{0} \quad$ initial concentration of pollutant

C concentration of pollutant after a time ' $\mathrm{t}$ '
$D_{o} \quad$ initial oxygen deficit

$D \quad$ oxygen deficit after travel time ' $\mathrm{t}$ '

$k_{a} \quad$ reaeration rate coefficient

$k_{C B O D} \quad$ CBOD decay rate coefficient

$k_{B O D} \quad$ BOD decay rate coefficient

$k_{d} \quad$ pollutant decay rate per day

$k_{20} \quad$ pollutant decay rate at $20^{\circ} \mathrm{C}$

$L_{o} \quad$ ultimate $\mathrm{BOD}$ in the river

$L_{n o} \quad$ ultimate NBOD in the river after mixing

$k_{n} \quad$ NBOD or AN decay rate

$k_{r} \quad$ CBOD removal rate coefficient

$t \quad$ travel time of stream

$T \quad$ temperature

$\theta \quad$ temperature correction factor

\section{References}

1. Kannel PR, Lee S, Lee YS, Kanel S, Pelletier G. Application of automated QUAL2Kw for water quality modeling and management in the Bagmati River, Nepal. Ecol. Model. 2007;202: 503-517.

2. Rauch W, Henze M, Koncsos L, et al. River water quality modelling: I. State of the art. Water Sci. Technol. 1998;38:237-244.

3. Ye H, Guo S, Li F, Li G. Water quality evaluation in tidal river reaches of Liaohe River estuary, China using a revised QUAL2K model. Chinese Geogr. Sci. 2013;23:301-311.

4. Sharma D, Kansal A. Assessment of river quality models: A review. Rev. Environ. Sci. Bio/Technol. 2013;12:285-311.

5. Tewilliger K, Wolflin P. Decision making for sustainable use and development. Coastal lagoons: Ecosystem processes and modeling for sustainable use and development. London: CRC Press; 2005. p. 331-370.

6. Moriasi D, Wilson B, Douglas-Mankin K, Arnold J, Gowda P. Hydrologic and water quality models: Use, calibration, and validation. Trans. Am. Soc. Agr. Biol. Eng. 2012;55:1241-1247.

7. Moriasi DN, Zeckoski RW, Arnold JG, et al. Hydrologic and water quality models: Key calibration and validation topics. Trans. Am. Soc. Agr. Biol. Eng. 2015;58:1609-1618.

8. Ji ZG. Hydrodynamics and water quality: Modeling rivers, lakes, and estuaries. John Wiley \& Sons; 2017.

9. Haider H, Ali W. Development of dissolved oxygen model for a highly variable flow river: A case study of Ravi River in Pakistan. Environ. Model. Assess. 2010;15:583-599.

10. Thomann RV, Mueller JA. Principles of surface water quality modeling and control. Harper \& Row, Publishers; 1987.

11. Bowie GL, Mills WB, Porcella DB, et al. Rates, constants, and kinetics formulations in surface water quality modeling. EPA; 1985. p. 3-85.

12. Campolo M, Andreussi P, Soldati A. Water quality control in the river Arno. Water Res. 2002;36:2673-2680.

13. Demars B, Manson J. Temperature dependence of stream aeration coefficients and the effect of water turbulence: A critical review. Water Res. 2013;47:1-15.

14. Bahadur R, Amstutz DE, Samuels WB. Water contamination 
modeling - A review of the state of the science. J. Water Resour. Prot. 2013;5:142-155.

15. González SO, Almeida C, Calderón M, Mallea M, González P. Assessment of the water self-purification capacity on a river affected by organic pollution: Application of chemometrics in spatial and temporal variations. Environ. Sci. Pollut. Res. 2014;21:10583-10593.

16. Menezes JPCd, Bittencourt RP, Farias MDS, Bello IP, Oliveira LFCd, Fia R. Deoxygenation rate, reaeration and potential for self-purification of a small tropical urban stream. Revista Ambiente \& Água 2015;10:748-757.

17. Ji ZG. Hydrodynamics and water quality: Modeling rivers, lakes, and estuaries. John Wiley \& Sons; 2008.

18. Chapra S. Surface-water quality modeling. New York: McGrawHill; 1997. p. 560-575.

19. Haider H. Water quality management model for Ravi River. Lahore: Univ. of Engineering \& Technology; 2010.

20. Pescod M. Wastewater characteristics and effluent quality parameters. Wastewater treatment and use in agriculture. Food and Agriculture Organization of the Unitied Nations; 2013.

21. Chapra SC. Surface water-quality modeling. Waveland press; 2008.

22. Tchobanoglous G, Burton FL, Stensel D. Wastewater engineering: Treatment and reuse. New York: McGraw-Hill; 2003.

23. Federation WE. Standard methods for the examination of water and wastewater. Washington D.C., USA: American Public Health Association (APHA); 2005.

24. Sullivan AB, Snyder DM, Rounds SA. Controls on biochemical oxygen demand in the upper Klamath River, Oregon. Chem. Geol. 2010;269:12-21.

25. Tu Y, Chiang P, Yang J, Chen S, Kao C. Application of a constructed wetland system for polluted stream remediation. $J$. Hydrol. 2014;510:70-78.

26. Ambrose R, Wool T. WASP7 stream transport-model theory and user's guide, supplement to water quality analysis simulation program (WASP) user documentation. National Exposure Research Laboratory, Office of Research and Development, US Environmental Protection Agency, Athens, Georgia; 2009.

27. Zhang R, Qian X, Yuan X, Ye R, Xia B, Wang Y. Simulation of water environmental capacity and pollution load reduction using QUAL2K for water environmental management. Int. J. Environ. Res. Public Health 2012;9:4504-4521.

28. Zhang R, Qian X, Li H, Yuan X, Ye R. Selection of optimal river water quality improvement programs using QUAL2K: A case study of Taihu Lake Basin, China. Sci. Total Environ. 2012;431:278-285.

29. Fan C, Wang WS, Liu KFR, Yang TM. Sensitivity analysis and water quality modeling of a tidal river using a modified streeter-phelps equation with HEC-RAS-calculated hydraulic characteristics. Environ. Model. Assess. 2012;17:639-651.

30. Yang Y, Wang L. A review of modelling tools for implementation of the EU water framework directive in handling diffuse water pollution. Water Resour. Manage. 2010;24:1819-1843.

31. Fan C, Ko CH, Wang WS. An innovative modeling approach using Qual2K and HEC-RAS integration to assess the impact of tidal effect on river water quality simulation. J. Environ. Manage. 2009;90:1824-1832.
32. Ostapenia AP, Parparov A, Berman T. Lability of organic carbon in lakes of different trophic status. Freshwater Biol. 2009;54: 1312-1323.

33. Volkmar EC, Dahlgren RA. Biological oxygen demand dynamics in the lower San Joaquin River, California. Environ. Sci. Technol. 2006;40:5653-5660.

34. Radwan M, Willems P, El-Sadek A, Berlamont J. Modelling of dissolved oxygen and biochemical oxygen demand in river water using a detailed and a simplified model. Int. J. River Basin Manage. 2003;1:97-103.

35. Park SS, Lee YS. A water quality modeling study of the Nakdong River, Korea. Ecol. Model. 2002;152:65-75.

36. Zhang R, Gao H, Zhu W, Hu W, Ye R. Calculation of permissible load capacity and establishment of total amount control in the Wujin River Catchment - A tributary of Taihu Lake, China. Environ. Sci. Pollut. Res. 2015;22:11493-11503.

37. Allam A, Fleifle A, Tawfik A, Yoshimura C, El-Saadi A. A simulation-based suitability index of the quality and quantity of agricultural drainage water for reuse in irrigation. Sci. Total Environ. 2015;536:79-90.

38. Fleifle A, Saavedra O, Yoshimura C, Elzeir M, Tawfik A. Optimization of integrated water quality management for agricultural efficiency and environmental conservation. Environ. Sci. Pollut. Res. 2014;21:8095-8111.

39. Rafiee M, Ali A, Mohammad A, et al. A case study of water quality modeling of the Gargar River, Iran. J. Hydraul. Struct. 2014;1:10-22.

40. Haider H, Ali W, Haydar S. Evaluation of various relationships of reaeration rate coefficient for modeling dissolved oxygen in a river with extreme flow variations in Pakistan. Hydrol. Process. 2013;27:3949-3963.

41. Park JY, Park GA, Kim SJ. Assessment of future climate change impact on water quality of Chungju Lake, South Korea, using WASP coupled with SWAT. JAWRA J. Am. Water Resour. Assoc. 2013;49:1225-1238.

42. Marsili-Libelli S, Giusti E. Water quality modelling for small river basins. Environ. Model. Softw. 2008;23:451-463.

43. Chapra S, Pelletier G, Tao H. QUAL2K: A modeling framework for simulating river and stream water quality: Documentation and users manual. Civil and Environmental Engineering Dept., Tufts University, Medford, MA; 2003.

44. Hvitved-Jacobsen T. The impact of combined sewer overflows on the dissolved oxygen concentration of a river. Water Res. 1982;16:1099-1105.

45. Terry J, Morris E, Bryant C. Water-quality assessment of White River between Lake Sequoyah and Beaver Reservoir, Washington County, Arkansas [Missouri]. Water-resources investigations (USA); 1983.

46. Bhargava D. Most rapid BOD assimilation in Ganga and Yamuna rivers. J. Environ. Eng. 1983;109:174-188.

47. Gowda TH. Modelling nitrification effects on the dissolved oxygen regime of the Speed River. Water Res. 1983;17: 1917-1927.

48. Grenney WJ, Kraszewski AK. Description and application of the Stream Simulation and Assessment Model Version IV (SSAM IV). Office of Biological Services, Fish and Wildlife Service, US Department of the Interior; 1981. 